\title{
特集 エボラ出血熱との戦いの総括
}

\section{1.エボラウイルス病＼cjkstart終息に向けて}

\section{古 宮 伸 洋}

日本赤十字社和歌山医療センター 感染症内科部

西アフリカで甚大な被害をもたらしたエボラウイルス病 (Ebola Virus Disease: EVD) 流行は対策強 化の成果として現在のところほぼ終息している.

EVD に関する新たな知見が多く得られた一方で，不明な部分も多く残されている．エボラウイル スが患者体内に長期間存在し感染源になりうることが示されたがその機序は不明である. 治療におい ては画期的な治療方法はなく，古典的な支持療法が基本となることに変わりはない．新しく開発され たワクチンは曝露後接種であっても高い有効性を示した，検查では迅速診断キットの開発が進められ ている.

現地では「患者発生ゼロの継続」を目標として, 患者発生時の早期探知及び対応, 医療施設におけ る基本的な感染対策の強化が進められている. 落ち着いた状況になりつつあるが, エボラ生還者(Ebola survivor）が偏見や後遺症に悩まされている状況は続いている.

流行によって医療, 経済や教育に至るまで社会全体がダメージを受けており, 流行再燃のリスクも 依然として存在している。保健医療システムを包括的に強固にすることが EVD を含めた様々な感染 症の流行への備えとして望まれる.

\section{はじめに}

2016 年 3 月 29 日，世界保健機関（WHO）は，西アフ リカで甚大な被害をもたらしたエボラウイルス病 (Ebola Virus Disease: EVD) の流行に関して PHEIC (Public Health Emergency of International Concern : 国際的に懸 念される公衆衛生上の緊急事態) の終了を宣言した。宣言 後もわずかに患者は発生しているが, 2013 年 12 月に始まっ てから約 2 年間続いた流行に一つの区切りが付けられたこ とになる。この間に西アフリカでは 28,000 人以上の患者, 11,000 人以上の死亡者が報告された.

西アフリカでEVD が猛威を振るった 2015 年 4 月頃まで

連絡先

干 640-8558

和歌山県和歌山市小松原通 4-20

日本赤十字社和歌山医療センター

TEL: 073-422-4171

FAX: 073-426-1168

E-mail:komiyanobuhiro@yahoo.co.jp
の状況に関しては既に有馬らが本誌に報告しているため 1$)$, 本稿ではこの流行がコントロールされ始めた 2015 年以降 から現在 (2016 年 4 月執筆) に至る現地の状況, 及び臨 床研究で得られた知見を中心に述べる.

\section{西アフリカでの EVD 流行}

2013 年 12 月, ギニア共和国から始まった流行は国境を 超え, 隣国のシェラレオネ, リベリアに広がっていった。 2014 年 3 月にギニアでの EVD 発生が探知されて以降, WHO を中心に流行国に対して国際的な支援が続けられて いたが拡大を止めることは出来ず，2014 年 7 月頃からは これら 3 力国の首都圈を中心に患者数が急速に増大し, 周 辺国（マリ，ナイジェリア，七ネガル）にも患者が認めら れるようになった。

流行当初は国際社会の反応は鈍かったが, 欧米での患者 発生などをきっかけに徐々に危機感が高まり, 同年 8 月に WHO はPHEIC であるとの宣言を出した。 流行規模が拡 大したことで健康分野だけでなく経済, 流通, 教育など他 分野に渡る大規模な支援, 調整が必要となり, 国連は WHO だけでは対応困難と判断し, 2014 年 9 月に国連エボ ラ緊急対応ミッション (UNMEER: UN Mission for Ebola Emergency Response) を立ち上げ，さまざまな国際機関に 


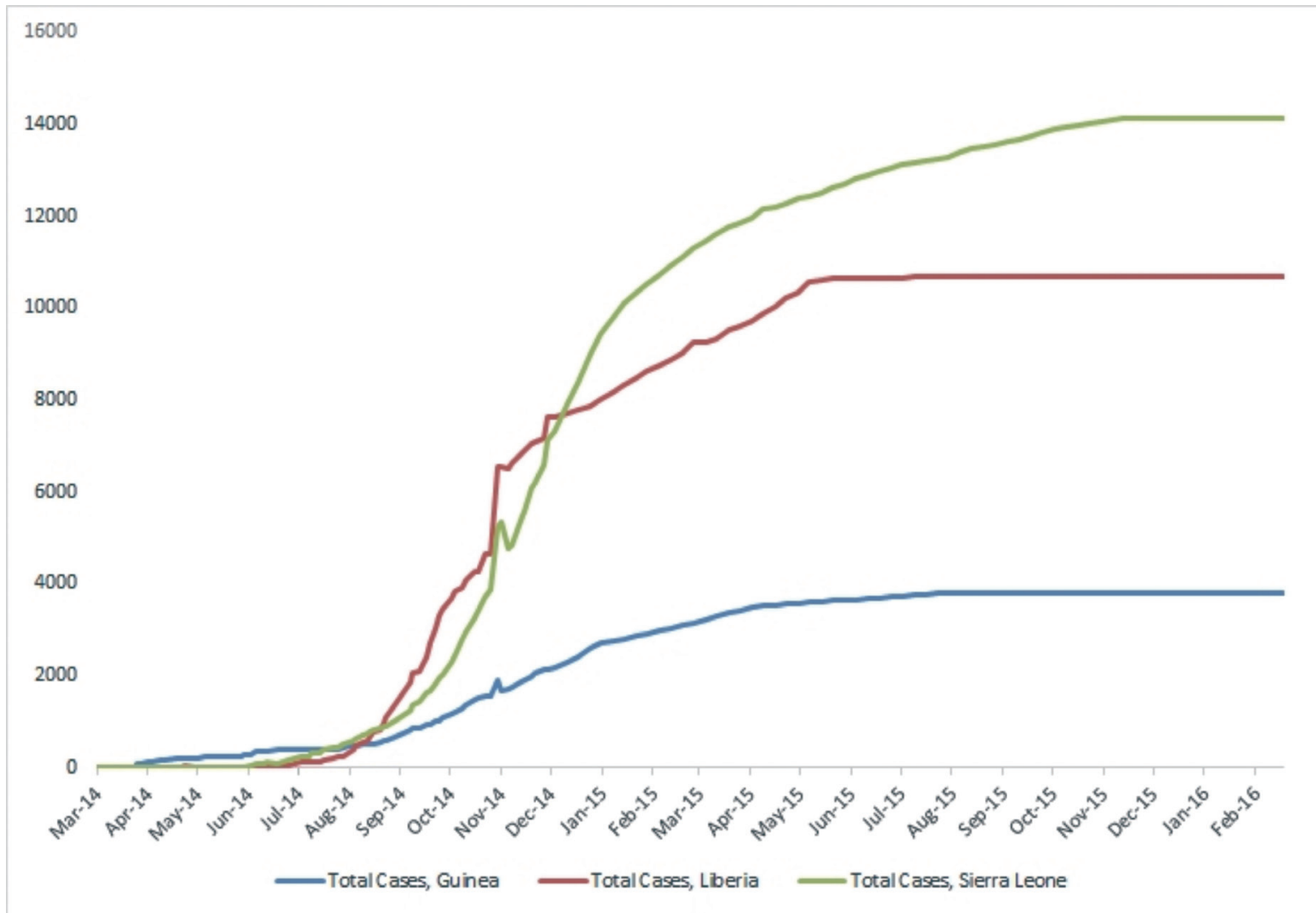

\section{図 12014 年 3 月からの国別の EVD 累積患者数（疑い例含む）}

引用）米国 CDC ホームページ：

http://www.cdc.gov/vhf/ebola/outbreaks/2014-west-africa/case-counts.html

よる支援をリードするようになった．

UNMEERを中心とした対策の目標はまずは流行をス ローダウンさせることであったが, エボラ治療施設の充実, 啓発活動など様々な対策が奏功し, 2014 年 11 月前後をピー クに以降の患者発生数は徐々に減少した（図 1)。2015 年 に入り流行がコントロールされ始めたため UNMEER は 2015 年 6 月 31 日にその役目を終元解散した。その後, WHO や現地政府は「患者発生ゼロの継続」を目標として 掲げ，住民啓発，サーベイランスシステム構築，医療機関 の対応能力向上などの活動を継続している.

WHO は，EVDの最後の確定患者からウイルスが消失し たことが確認されてから，42 日間（最大潜伏期間の 2 倍） 新たな患者発生がなかった場合に流行終息宣言を出すこと にしている．2015 年 5 月に最初にリベリアで終息宣言が 出された。 シェラレオネ, ギニアは限定された地域内で患 者が少数発生する状況がしばらく続いたが，徐々にコント ロールされるようになり同年 11 月にシェラレオネで, 12 月にはギニアでもそれぞれ終息宣言が出された。

しかしながら，終息宣言が出された以降もそれぞれの国 で患者の再発生と再度の終息宣言が繰り返された。リベリ
アでは終息宣言が出された翌月の 6 月末には 3 名の患者が 発生した。この患者の感染源は不明だったが，早期対応に よりそれ以上の拡大を阻止することが出来た。その後しば らく患者発生はなく同年 9 月に 2 回目の終息宣言が出され たが，11月には再び 3 名の患者が発生した。この事例の 詳細もはっきりはしていないが，EVD から回復した生還 者 (Ebola survivor) からの感染が疑われている ${ }^{2)}$.2016 年 1 月には 3 回目の終息宣言が出されたが，4月にはギニア からリベリアに持ち込まれたと考えられる事例が発生し た。 ギニアでは 2016 年 3 月に 8 名の患者が発生し, 前述 のように国境を超えてリベリアに飛び火した。 シェラレオ ネでは 2016 年 1 月に 2 名の患者が発生したが, それ以上 の患者発生はなく 3 月 17 日に 2 回目の終息宣言を出した.

\section{終息宣言後の患者発生}

いったん感染の連鎖を断ち切ったと思える状況でなぜ新 たな患者が発生するのか。 サーベイランス体制が不十分な ことや EVD 患者を隠す地域があることで潜在する感染の 連鎖を探知出来ていない可能性，コウモリなど自然界から 新たにウイルスが持ち込まれた可能性などが考えられる 
が，いくつかの事例では，EVD から回復した患者の体内 にウイルスが長期間残存していることが原因である可能性 が考えられている。 エボラウイルスは眼房水や髄液などの 部位で長期生存できることが知られているが，特に感染性 の面から注目されているのは精液である.

2015 年 3 月, リベリアの首都モンロビア近郊で 44 歳の 女性が EVD と診断された。彼女は発症の 13 日前にエボ ラ生還者と性行為を行って㧍り, 性行為により感染したと 考えられている。性の発症を受けて発端となった生還者 について精液の PCR 検查を行ったところ陽性であった. 実に発症後 199 日目にして PCR 検査が陽性であったこと になる ${ }^{3)}$ ，ただし性行為により感染したという正式な論文 報告はこのケース以外にないため，かなり稀なケースであ ると考えられる，PCR 検查陽性であることと感染性とは イコールではなく，感染の危険がある期間についてはまだ 不明であるが, 生還者の精液検査をフォローした研究では 少なくとも 9 ケ月程度は PCR 陽性が持続するケースがあ ることが報告されている ${ }^{4,5)}$.

女性の生還者からの感染例は報告されていないが，発症 後 33 日目の胵分泌液が PCR 陽性となったケースがある ${ }^{6)}$. 発症後 16 ケ月にわたって母乳中から PCR 検査が陽性と なったケースの報告があるため，WHO は母乳が出る患者 には母乳の PCR 検査を行うことを推奨している ${ }^{7)}$.

エボラウイルスが長期間，患者体内に残存することの出 来るメカニズムに関しては明らかではないが，いずれの研 究でも時間の経過とともに体内からウイルスは消失してい くことを示しており，西アフリカでエボラ生還者から感染 する危険性は今後低下していくと考えられている.

\section{臨床研究の状況}

西アフリカで臨床研究を進めることは大変困難であった と報告されている ${ }^{8)}$. 困難であった理由として, 診療録の 記載などが不十分で信頼性の高いデー夕を得ることが出来 ない場合があること，治療法の限られた致死率の高い疾患 であるため倫理面の問題があったことなどが挙げられる. またエボラ治療施設に対する風説も流れるなど政府や海外 支援団体に対して住民の不信感が強い地域もあった。この ような背景のため多くの治療施設ではランダム化比較試験 などを行うことは出来ず，観察研究が中心になった．

治療に関して，現在までに有効性を示すことの出来た特 異的治療法はない，流行の後半になってファビピラビルと 回復期血漿について過去の症例群（Historical control）と 比較する介入研究が行われたが，いずれも有効性を示すこ とが出来なかった 8,9 . 同様に脂質ナノ粒子を利用した siRNA 複合体である TKM-100802 も有効性を示すことは 出来なかった ${ }^{10)}$. ZMapp を初めとするいくつかのモノク ローナル抗体治療薬は期待されているものの生産量の問題 などから大規模な研究に至っておらず，限られた症例数か
ら臨床的な有効性を示すことは困難であると考えられる． これらの薬剤はいずれも患者の治療効果を証明することが 出来ていないが，理論的には発症後の使用では遅すぎる可 能性があり, 曝露後予防治療として使用された場合の有効 性に関しては可能性を残している.

現在の見解では十分な補液などの支持的治療が治療の根 幹である。西アフリカ現地での EVD の致死率は 37 $74 \%$ であったが，欧米に搬送されて高度な医療を受けた 27 名のうち死亡は 5 名（致死率 $18.5 \%$ ）であった ${ }^{11)}$ 。年 齢や基礎疾患など患者背景に違いがあるため単純に比較す ることは出来ないが，集中的な循環呼吸管理をすることで 致死率を下げることが可能なことが示唆された。

治療効果の高い薬剤がない一方で，遺伝子組み換えウイ ルス（Recombinant Vesicular Stomatitis Virus）を利用し たワクチンは EVD 患者への接触者を対象に曝露後接種し た研究で非常に高い効果が示した ${ }^{12}$. この研究結果によっ て西アフリカでは患者発生時の封じ込妨策の一つとして 接触者へのワクチン接種 (Ring vaccination) が行われるよ うになっている ${ }^{13)}$.

検査診断では PCR 検査以外にもいくつかの検査法が開 発されている。指先採血（毛細管血）を検体とする $\mathrm{ReEBOV}^{\mathrm{TM}}$ 迅速診断キットは高い感度を示し ${ }^{14)}$, WHO も使用に関するガイダンスを公表した ${ }^{15)}$. 唾液検体を用 いる OraQuick ${ }^{\circledR}$ 迅速診断キットは, シェラレオネなどで 研究も兼ねて EVD 疑いの遺体のスクリーニング検査とし て使用されている ${ }^{16)}$ ，その他にも GeneXpert ${ }^{\circledR}$ を用いた検 査などが開発されている ${ }^{17)}$.

\section{流行終息後の現地状況}

筆者は流行初期の 2014 年 4 月と流行ピーク期の同年 9 月にリベリアを, 流行終息期の 2016 年 3 月にシェラレオ ネを訪問する機会を得た。

流行初期に地域を訪れた時には, 実際の患者が周囲にい なかったこと、これまで西アフリカで流行したことのない 感染症であったことなどから, EVDの存在を認めない住 民も多かった，流行ピーク期のリベリアでは一転して住民 の間に感染への恐れと緊迫感が広がっており, 神経質なま でに手を洗い，挨拶のための握手もしなくなっていた，ラ ジオニュースのほとんどは EVD 関連であり，街中にはい たるところに啓発のためのポスターが貼られていた。しか し 2016 年 3 月のシェラレオネ訪問時にはそのような異常 な緊迫感は既に認められなかった，首都フリータウンの空 港での手洗い, 健康状態于ェックは依然として続けられて いたが形式的なものでそれほど厳密に行っている様子では なかった，啓発のためのポスターもあまり目立たなくなっ ていた，ただスーパーなど人の集まる施設の入り口には手 洗いステーションが設置されており，手指衛生は習慣とし て根付いているようであった。 


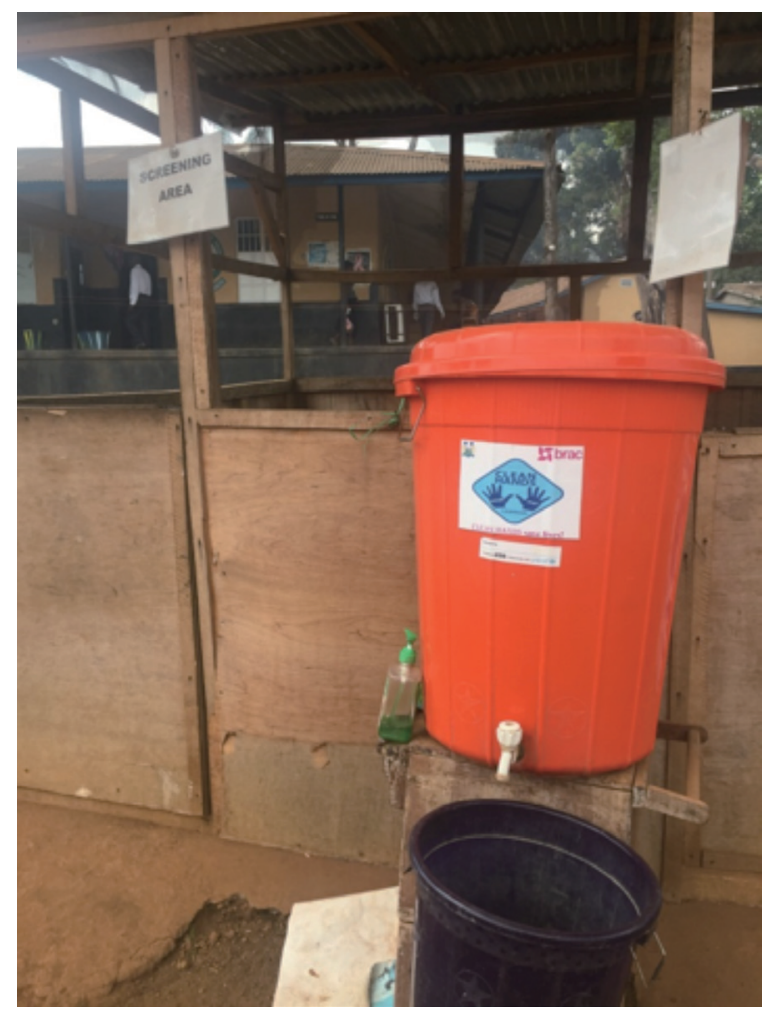

写真 1）地域診療所に設置された EVD 疑い患者スクリーニング施設

2016 年に入ってから西アフリカでの感染の連鎖は基本 的には断ち切ることが出来ているため, 政府を主体とする EVD 対策としては今後の散発事例発生時の早期探知及び 対応，一般医療施設に扔ける基本的な感染対策の強化が求 められていた。

早期探知のためにはサーベイランスの強化が必須である が, シェラレオネのいくつかの地域では 2014 年末に米国 CDC の支援の元にCEBS (Community Event Based Surveillance) と呼ばれるシステムが導入されていた ${ }^{18)}$. これは EVDを疑う事例が発生した時には, 現場の担当者 がスマートフォンなどで利用できる SMS (Short message service）を用いて簡単に地域の対応チームに報告するこ とが出来るシステムであり, 迅速な対応につながることが 期待されている.

患者発生がほとんどないため，筆者が訪問した 2016 年 3 月にはシェラレオネ国内で稼働しているエボラ治療施設 は首都フリータウンに一つだけであったＥVDを疑う事 例が発生した場合にはまず郡病院などに設置されているス クリーニング施設（写真 1), あるいは一時収容施設 （Holding center）に収容することになっている．国内の 複数箇所に PCR 検查が行える検査施設が設置されている ので検査は迅速に行うことが出来る. 診断確定した場合に は患者を前述のエボラ治療施設に搬送するというシステム になっている。
医療従事者はEVDに罹患するリスクが高いが，シェラ レオネではエボラ治療施設で感染した医療従事者はわずか 1 割に過ぎず，多くは他の一般医療機関において感染した と報告されている ${ }^{19)}$ ：シェラレオネには 1264 の医療機関 (病院は 40 施設) があり, 2 つ国立病院を頂点にして, 郡病院, 地域診療所とピラミッド型の医療システムが整備 されている，発熱などを主訴として EVD 患者が受診する 一般医療機関においては，疑い患者のスクリーニングと基 本的な感染対策のレベル向上が重要である。訪問した国立 病院や郡病院では感染管理に関するポスターが多く掲示さ れ，各病室の入り口などには手洗い場が設けられており， 感染対策にしっかり取り組んだスタッフを表彰するなど, EVD 流行終息後も感染管理意識を高く保つ取り組みがな されていた。

\section{エボラ生還者の抱える問題}

西アフリカには 17,000 人以上のエボラ生還者がいると 推定されている. EVDに対する不安感, 患者に対する偏見・ 差別は時間とともに軽減していたが，前述のように生還者 の体内にウイルスが長期間残存することが明らかになり， 感染源となりうる可能性が強調されるようになり生還者へ の偏見·差別が再び悪化してきている.中にはコミュニティ から受け入れてもらえずに引っ越しを余儀なくされたエボ ラ生還者も多数存在する. 
生還者の多くは後遺症にも苦しめられていることが報告 されている。シェラレオネでの研究では生還者に関節障害 (76\%), 眼症状 (60\%), ぶどう膜炎 (18\%), 聴力症状 (24\%) が認められている。後遺症の生じる機序は不明であるが, 急性期のウイルス量がぶどう膜炎の発症に相関していたと する報告がされている ${ }^{20)}$ ，再発は極めて稀であると考え られているが，英国で治療を受けて治癒していた患者が発 症後 9 ケ月してから髄膜炎をきたした症例が報告されてい る ${ }^{21)}$. こうした生還者の抱える健康問題への対応に関し てWHO はガイダンスを作成し ${ }^{7)}$ ，リベリアの首都モンロ ビアなど一部の地域では生還者のためのクリニック（Ebola survivors clinic）が設置されている.

今回の流行で EVDにより親を亡くした子供も多く, UNICEF は約 2 万 3000 人の子供が片親，あるいは両親を亡くして いると報告している。もともと西アフリカではコミュニ ティ内での助け合いの精神が強く, 両親が亡くなった場合 には親戚等が子供を引き取って育てていくことが伝統的に 行われてきた。しかし EVDで親が亡くなった場合は感染 を恐れて子供の引き取り手のいない事例が多く見られた。 現在も EVD 孤览問題の対策としてコミュニティに理解を 求め孤児を親族に引き取ってもらえるように導く啓発活動 や，孤児院の整備が行われている。

\section{さいごに}

今回の EVD 流行は患者やその関係者だけでなく，現地 の社会全体に大きなダメージを残している．医療面では犠 牲となった医療者が多かったために人材不足が生じている こと，EVDに医療リソースを集中したことで，マラリア など現地で最も流行している感染症の対策や母子保健，慢 性疾患の治療，定期予防接種などが滞った状態が続いたこ とにより今後長期的な問題につながる可能性が指摘されて いる，流行期間中の国境閉鎖や外出禁止，マーケットの閉 鎖による経済的な損失も大きい。また流行各国に扔いて半 年間程度学校が閉鎖されていたので，教育への影響も懸念 されている。これらの問題は未だ復興途上にある.

エボラウイルスが自然界に存在する以上は，今後またど こかで流行が発生する可能性がある。またエボラウイルス 以外にも同様のアウトブレイクを起こしうる新興感染症は いまも世界各地で発生している。西アフリカで過去に例を 見ない規模の EVD の流行が起こった背景には貧困，教育 問題，脆弱な医療体制がある。今後医療機関の充実だけで なく，住民の衛生，インフラの整備などまで含めた包括的 な保健医療システムの基盤を強固なものにしていくことが EVD を含めた様々な感染症の流行への備えとして望まれ る.

今回の流行の発生した西アフリカの 3 カ国は最貧国に位 置づけられる国々である。現地政府だけではこれらの課題 に取り組むことは困難であり，国際社会による支援の継続
が必要とされる

本稿に関連し，開示すべき利益相反関係にある企業等は ありません。

\section{参考文献}

1 ) 有馬雄三, 島田智恵.西アフリカのエボラウイルス病 発生状況 .ウイルス Vol. 65 (2015) No. 1 p. 47-54

2 ) WHO. Ebola Situation Report - 16 December 2015 http://apps.who.int/ebola/current-situation/ebolasituation-report-16-december-2015

3 ) Mate SE, Kugelman JR, Nyenswah TG,et al. Molecular Evidence of Sexual Transmission of Ebola Virus. N Engl J Med. 373(25):2448-54, 2015

4 ) Deen GF, Knust B, Broutet N, et al. Ebola RNA Persistence in Semen of Ebola Virus Disease Survivors Preliminary Report. N Engl J Med. 2015 Oct 14. [Epub ahead of print]

5 ) Uyeki TM, Erickson BR, Brown S, et al. Ebola virus persistence in semen of male survivors. Clin Infect Dis. 2016 Apr 3. [Epub ahead of print].

6 ) Fischer WA, Wohl DA.Confronting Ebola as a Sexually Transmitted Infection. Clin Infect Dis. 2016 Mar 1. [Epub ahead of print]

7 ) WHO. Clinical care for survivors of Ebola virus disease Interim guidance. http://www.who.int/csr/ resources/publications/ebola/guidance-survivors/ en/

8 ) Sissoko D, Laouenan C, Folkesson E, et al. Experimental Treatment with Favipiravir for Ebola Virus Disease (the JIKI Trial): A Historically Controlled, Single-Arm Proof-of-Concept Trial in Guinea.

PLoS Med. 13(3):e1001967, 2016.

9 ) GriensvenJV, Edwards T, Lamballerie X, et al. Evaluation of Convalescent Plasma for Ebola Virus Disease in Guinea.N Engl J Med.374(1):33-42, 2016.

10) Dunning J, Sahr F, Rojek A, et al. Experimental Treatment of Ebola Virus Disease with TKM-130803: A Single-Arm Phase 2 Clinical Trial. PLoS Med. 13(4):e1001997, 2016.

11) Uyeki TM, Mehta AK, Davey RT Jr, et al. Clinical Management of Ebola Virus Disease in the United States and Europe. N Engl J Med. 374(7):636-46,2016.

12) Henao-Restrepo AM, Longini IM, Egger M, et al. Efficacy and effectiveness of an rVSV-vectored vaccine expressing Ebola surface glycoprotein: interim results from the Guinea ring vaccination cluster-randomised trial. Lancet. 386(9996):857-66, 2015.

13) WHO coordinating vaccination of contacts to contain Ebola flare-up in Guinea

http://www.who.int/features/2016/ebola-contactsvaccination/en/

14) Broadhurst MJ, Kelly JD, Miller A, et al. ReEBOV Antigen Rapid Test kit for point-of-care and laboratory-based testing for Ebola virus disease: a field validation study Lancet. 386(9996):867-74, 2015.

15) WHO. Interim guidance on the use of rapid Ebola antigen detection tests 
http://www.who.int/csr/resources/publications/ ebola/ebola-antigen-detection/en/

16) WHO Emergency Use Assessment and Listing for Ebola Virus Disease IVDs PUBLIC REPORT.

http://www.who.int/diagnostics_laboratory/procurement/160324_final_public_report_ea_0023_021_00_ copy.pdf\#search=\%27oraquick+ebola + sierra+leo ne $\% 27$

17) Semper AE, Broadhurst MJ, Richards J, et al. Performance of the GeneXpert Ebola Assay for Diagnosis of Ebola Virus Disease in Sierra Leone: A Field Evaluation Study. PLoS Med. 13(3):e1001980, 2016.

18) Crowe S, Hertz D, Maenner M, et al. A plan for community event-based surveillance to reduce Ebola transmission - Sierra Leone, 2014-2015. MMWR Morb Mortal Wkly Rep. 64(3):70-3, 2015.

19) OluEmail O, Kargbo B, Kamara S, et al. Epidemiology of Ebola virus disease transmission among health care workers in Sierra Leone, May to December 2014: a retrospective descriptive study. BMC Infectious Diseases.15:416,2015

20) Mattia JG, Vandy MJ, Chang JC, et al. Early clinical sequelae of ebola virus diseases in Sierra Leone: a cross-sectional study)

21) WHO. Clinical care for survivors of Ebola virus disease Interim guidance http://www.who.int/csr/resources/publications/ ebola/guidance-survivors/en/

\title{
Ebola virus disease: the road to zero
}

\author{
Nobuhiro KOMIYA \\ Japanese Red Cross Wakayama medical center Department of Infectious Diseases \\ 4-20, Komatsuharadori, Wakayama City, Japan
}

While ebola virus disease (EVD) outbreak in West Africa seemed to be subsided, there are still some sporadic cases reported from the field.

Many studies were conducted during the outbreak. It was identified that the virus can survive for a long period in certain areas of the survivors and they can be a reservoir. But the mechanism is still unknown. Currently no specific drug for EVD is established and classic supportive therapy was the mainstay of the treatment. A new ebola vaccine candidates appear to be highly effective for postexposure prophylaxis. Rapid diagnostic tests are under development.

In West Africa, Ebola response and recovery efforts to achieve and to sustain a "resilient zero" are ongoing. The situation in the communities is stabilized but ebola survivors are still suffering both from stigma and sequelae.

EVD outbreak damaged affected countries' health, economic and education systems. The risk of re-outbreak is still remained. It is important to strengthen comprehensive public health system to prevent the future emerging disease outbreaks. 